\title{
Sustainable development of recreation and tourism
}

\author{
Manish Kumar $^{1}$, Dr. Nilesh Arora ${ }^{1}$, and Dr. Prashant Kumar Gautam² \\ ${ }^{1}$ Chandigarh University, India \\ ${ }^{2}$ Panjab University, India
}

\begin{abstract}
Over the period of time, responsible and sustainable development have become very important phenomenon and integrating with each form of development. When it comes to tourism and its various forms then it plays a significant role in order to develop, retain and sustain the tourism for the future generation even without compromising the present needs, wants and desires of tourists, local residents and stakeholders. Therefore, the present study has measured the impacts and relationship between sustainable development and recreation (most common form of tourism) and tourism development. This is an empirical research conducted through both quantitative and qualitative approaches and methods. Sample of 100 respondents which includes tourists, local residents, tourism stakeholders, tourism professionals, academician and research scholars has been collected via self-administrated standardized questionnaire or tool name; Sustainable Development Measurement Scale (SDMS) over five point Likert Scale. SDMS have ten distinct and specific items related to sustainable development with reference to recreation and tourism development. Collected data has been analysis with the help of both descriptive and inferential statistics such as correlation coefficient and SEM (Structural Equation Modeling). Findings of the study suggested that sustainable development has high positive correlation with recreation and tourism development and also significantly impacting both recreation and tourism development at tourism destinations. On the basis of researcher findings appropriate suggestions and recommendations were also made in relation to sustainable recreational tourism development.
\end{abstract}

\section{Introduction}

Sustainable tourism development is a popular trend in the present form of tourism development over the destinations under various forms of tourism such as eco, rural, village, leisure and recreation, adventure, pilgrimage and medical etc. However, there could have been different confusion among the minds of tourist, local residents, tourism stakeholders and various other organizations which are directly and indirectly associated with tourism about the achievement and integration of sustainable development with tourism and its forms. Therefore several questions would arises like is it possible to integrate tourism with sustainable development, how to implement core indicators of sustainability with recreation and tourism development, as tourism is vast industry and have uncountable forms then at what extent sustainable development could be possible and many more questions. All these 
questions leads to developmental gap between tourism and sustainable development, which is prime aim of the present study. [46] worked on implementing of sustainable tourism as pro-poor and community development approach wherein he has discussed and highlighted various relationships and impacts of sustainable development of tourism with local communities development, poverty elevation and growth and development of new form of tourism under core indicators of sustainability given by UNWTO (United Nations World Tourism Organizations). With reference to the above study it has been more clear that sustainable tourism development in the most necessity of present time in order to develop the tourism in most appropriate, responsible and sustainable manners. Similarly, present research would have signified relationships and impacts of sustainable development on recreation and tourism development under various parameters of sustainability. Moreover, sustainable development has huge impacts of each stage of tourism development from exploration to decline or rejuvenation. Thus, sustainable development is the tool and comprehensive approach for tourism growth and development.

\section{Review of literature}

The sustainable development explains an integrated platform in which development has evolved itself with various components of tourism and associated domains. The components such as attractions, equipment, accessibility, accommodations, amenities and activities at various destinations, etc., all these components of tourism destinations connects among each other and destination through sustainable development. [52]; [43]; [48]; [44]; [49]. Tourism development process protect and promote through interconnected indicators of sustainable tourism development from starting to end point of the tourism. Other approaches adopted by sustainable development include integrated, comprehensive development, positive impacts of tourism and high level of perception and satisfaction among local communities, tourists and stakeholders towards tourism development [3]; [41];[54]; [29]. Sustainable development is widely used in tourism including hospitality, transportations and associated areas of tourism [47]; [51]; [60]; [41]. Sustainable development is inevitably process in view of developing and managing the tourism destination and entire system in responsible and sustainable ways. Recreation is imperiled in the tourism based purposes and forms because of the high demands and preference by the visitors and both domestic and international have highest choices towards recreational activities over the destinations [53]. Particular while going to visit destinations like India [58]; [50]; [59]. Eco, village, mountainous and green tourism destinations are more prone to unsustainable practices therefore for these destinations and tourism forms, there must be ensured utmost sustainable development [42]. Towards other forms of tourism, it is also equally important to move and follow sustainable tourism practices [49]; [57]; [56]; [41]. [50] Summarized different parameters of tourism development in relation to sustainable development and how to achieve sustainable tourism development in every area of tourism development. Further, tourists and stakeholders play a significant role while development tourism in sustainable manners, a study has been conducted on tourists' perception and satisfaction towards sustainable tourism development by [40] and followed by stakeholders' satisfaction towards sustainable Tourism Development in by [45].

\section{Analysis and interpretation}

With the help of extensive review of literature, following research objectives and hypotheses have been formulated;

1. To study the relation and impacts of sustainable development on recreation 
2. To measure the relationship and impacts of sustainable development on tourism development recreation

H1There is positive relation and significant impacts of sustainable development on

$>$ H02There is negative relationship and insignificant impacts of sustainable development on tourism development

For testing alternative hypothesis H1 "There is positive relation and significant impacts of sustainable development on recreation and achieving its corresponding objective is "To study the relation and impacts of sustainable development on recreation" Pearson correlation coefficient, Coefficient of determination R2 and Share of independent variable were calculated to see the significant relation and impacts of sustainable development towards recreation as purpose and form of tourism development, as recreation is most common form of purposive form of tourism development and results are computed in table 1.1.

Table 1. Summary Statistics of Co-efficient of Correlation between sustainable development and recreation.

\begin{tabular}{|c|c|c|c|c|c|}
\hline Group & $\begin{array}{c}\text { Independent } \\
\text { Variable }\end{array}$ & $\begin{array}{c}\text { Dependent } \\
\text { Variable }\end{array}$ & Correlation. & $\begin{array}{c}\text { Coefficient of } \\
\text { Determination R2 }\end{array}$ & $\begin{array}{c}\text { Share } \\
\text { of I.V }\end{array}$ \\
\hline Respondents & $\begin{array}{c}\text { Sustainable } \\
\text { Development }\end{array}$ & Recreation & $0.936^{* *}$ & 0.876 & $87.6 \%$ \\
\hline
\end{tabular}

**Significant at 0.01 level Primary Data

The Pearson correlation coefficient " $\mathrm{r}$ " has been calculated between sustainable development and recreation tourism over the responses of $(\mathrm{N}=100)$ respondents. Table 1 . depicts that value of Co-efficient of correlation, $r=0.936$, between sustainable development and recreation form of tourism which is significant at 0.01 level of significance. The table 1.1 also shows the coefficient of determination, R2 $=0.876$ (Square of correlation coefficient, r) which reflect the amount of variability in recreation that is shared by all the respondents with reference to tourism activities over the destinations and after converting this value into percentage it can say that sustainable development shares $87.6 \%$ of the variance in total recreational development due to tourism. Hence the proposed alternative hypothesis $\mathrm{H} 1$ "There is positive relation and significant impacts of sustainable development on recreation has been accepted and its corresponding objective is "To study the relation and impacts of sustainable development on recreation" is also being achieved.

From the share of independent variable (sustainable development) to dependent variable (Recreational development) it has come to know that sustainable development is impacting $87.6 \%$ of the overall development of the recreational activities over the destinations and remaining share of $12.4 \%$ would get share and impacted by other factors such as tourism development, infrastructure development, amenities and many more components of tourism development. 


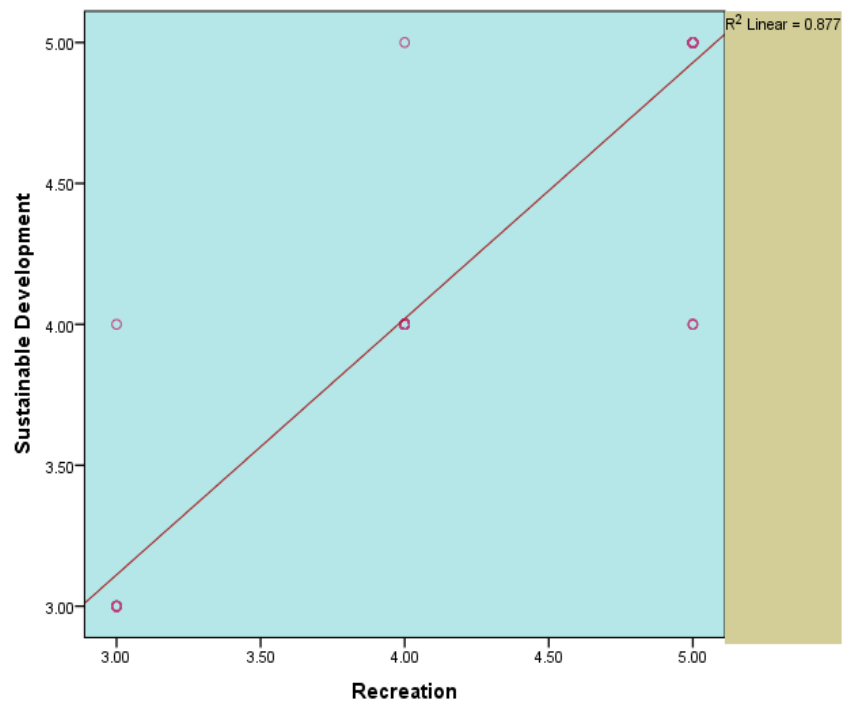

Fig. 1. Scatter plot of sustainable development and recreational development.

From the figure 1 it is clear that there is high positive correlation and significant impact of sustainable development of sustainable development on recreational development of the tourism.

In order to test null hypothesis "H02 There is negative relationship and insignificant impacts of sustainable development on tourism development" and achieving its corresponding objective is "To measure the relationship and impacts of sustainable development on tourism development "Pearson correlation coefficient, Coefficient of determination R2 and Share of independent variable were calculated to see the significant relation and impacts of sustainable development towards tourism development over the destination, as there could be sustainable practices needed to practices at destinations and results are computed in table 2 .

Table 2. Summary Statistics of Co-efficient of Correlation between sustainable development and recreation.

\begin{tabular}{|c|c|c|c|c|c|}
\hline Group & $\begin{array}{c}\text { Independent } \\
\text { Variable }\end{array}$ & $\begin{array}{c}\text { Dependent } \\
\text { Variable }\end{array}$ & Correlation. & $\begin{array}{c}\text { Coefficient of } \\
\text { Determination } \\
\text { R2 }\end{array}$ & $\begin{array}{c}\text { Share } \\
\text { of I.V }\end{array}$ \\
\hline Respondents & $\begin{array}{c}\text { Sustainable } \\
\text { Development }\end{array}$ & Recreation & $0.987 * *$ & 0.974 & $97.4 \%$ \\
\hline
\end{tabular}

**Significant at 0.01 level Primary Data

The Pearson correlation coefficient " $\mathrm{r}$ " has been calculated between sustainable development and overall tourism development over the responses of $(\mathrm{N}=100)$ respondents. Table 2. depicts that value of Co-efficient of correlation, $r=0.987$, between sustainable development and overall tourism development which is significant at 0.01 level of significance. The table 1.2 also shows the coefficient of determination, R2 $=0.974$ (Square of correlation coefficient, $r$ ) which reflect the amount of variability in recreation that is shared by all the respondents with reference to tourism development over the destinations and after converting this value into percentage it can say that sustainable development shares $97.4 \%$ of the variance in total tourism development. Hence the proposed null hypothesis H02 "There is negative relationship and insignificant impacts of sustainable development on tourism 
development" has been rejected and its corresponding objective is "To measure the relationship and impacts of sustainable development on tourism development" is also being achieved.

From the share of independent variable (sustainable development) to dependent variable (Overall tourism development) it has come to know that sustainable development is impacting $97.4 \%$ of the overall and total tourism development over the destinations and remaining share of $2.6 \%$ would get share and impacted by other factors such as infrastructure development, Government policies, integration of locals, tourists and stakeholders, amenities and many more components of tourism development.

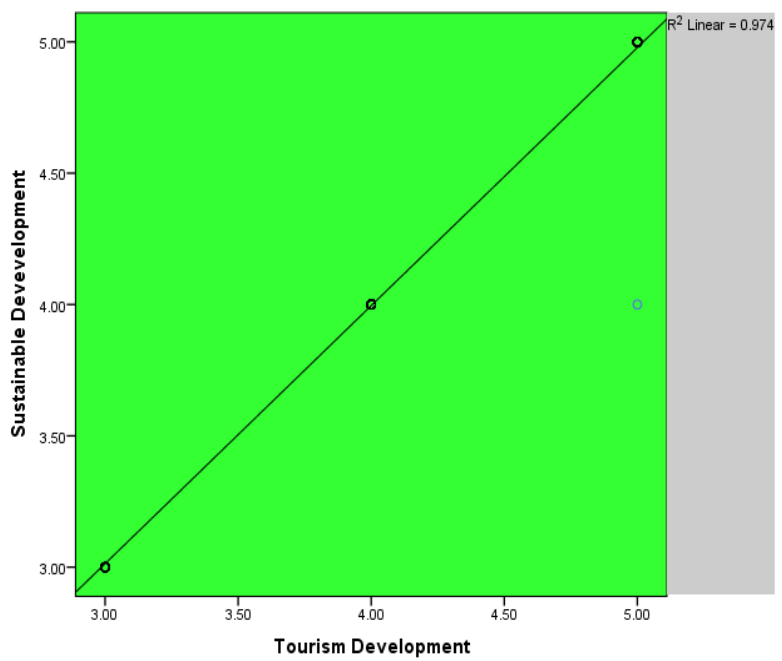

Figure 2. Scatter plot of sustainable Development and Tourism Development

From the figure 2 it is clear that there is very high positive correlation and significant impact of sustainable development on tourism development over the destinations.

\section{Conclusions}

1. Findings suggested that there is high positive correlation between sustainable development and recreational tourism activities as value of coefficient of determination, R2 $=0.876$ (Square of correlation coefficient, $r$ ) between them and share of independent variable (sustainable development) is $87.6 \%$ to dependent variable (recreational activities of tourism). Therefore, it is recommended to tourism planners, policy makers, stakeholders, tourists, local residents and other associated Governmental and non-governmental bodies that they must ensure effective integration of sustainable development with all kind of tourism recreational activities.

2. It has also been found sustainable development is significantly impacting development and processing of recreational tourism activities all across the destinations.

3. Results revealed that there is very high positive correlation between sustainable development and overall tourism development as value of coefficient of determination, R2 $=0.974$ (Square of correlation coefficient, $\mathrm{r}$ ) between them and share of independent variable (sustainable development) is $97.4 \%$ to dependent variable (overall tourism development). Therefore, it is recommended to tourism planners, policy makers, stakeholders, tourists, local residents and other associated Governmental and non-governmental bodies that they must 
ensure effective integration of sustainable development with overall and every form of tourism and also ensure fullest satisfaction to tourists, local residents and stakeholders through economic, socio-cultural and environmental development (TBL Model).

4. As suggested by findings sustainable development is very significantly impacting the growth and development of tourism and its various forms. Thus, tourism personnel should to minimize the negative impacts of tourism and vise-versa with positive impacts.

5. It is recommended to everyone who is associated with tourism and hospitality that they only plan, promote and development responsible and sustainable tourism development under core indicators of sustainability and under UNWTO (United Nations World Tourism Organizations) guidelines.

\section{References}

1. A. Agarwal, R. Shankar, M. K. Tiwari, Ind. Mark. Manag., 36(4), 443 (2007)

2. F. A. Alaba, M. Othman, I. A. T. Hashem, F. Alotaibi. J. Netw. Comput. Appl., 88, 10 (2017)

3. A. Al-Fuqaha, M. Guizani, M. Mohammadi, M. Aledhari, M. Ayyash, IEEE Commun. Surv. Tutor., 17(4), 2347 (2015)

4. M. Amiri, J. Sadaghiyani, N. Payani, M. Shafieezadeh, Manag. Sci. Lett., 1(3), 279 (2011)

5. D. Arunachalam, N. Kumar, J. P. Kawalek, Transp. Res. Part E: Logist. Transp. Rev., 114, 416 (2018)

6. R. Attri, N. Dev, V. Sharma, Res. J. Manag. Sci., 2319, 1171 (2013)

7. H. Bai, G. Zhou, Y. Hu, A. Sun, X. Xu, X. Liu, C. Lu, Food Control, 79, 35 (2017)

8. M. S. Balaji, S. K. Roy, J. Mark. Manag., 33(1-2), 7 (2017)

9. G. Baldini, M. Botterman, R. Neisse, M. Tallacchini, Sci. Eng. Ethics, 24(3), 905 (2018)

10. H. Bauer, M. Patel, J. Veira, McKinsey Insights (2015) https://www.mckinsey.com

11. A. Bedekar, IoT in India (2017) http://www.startupcity.com

12. Beecham Research, The future of retail through internet of things (2016) https://www.intel.in

13. M. Ben-Daya, E. Hassini, Z. Bahroun, Int. J. Prod. Res., 1 (2017)

14. Z. Bi, L. Da Xu, C. Wang, IEEE Trans. Ind. Inform., 10(2), 1537 (2014)

15. E. Borgia, Comput. Commun., 54, 1 (2014)

16. G. Bressanelli, M. Perona, N. Saccani, Int. J. Prod. Res., 1 (2018)

17. E. Brynjolfsson, Y. Hu, M. S. Rahman, Manag. Sci., 55(11), 1755 (2009)

18. J. Bughin, M. Chui, J. Manyika, McKinsey Q., 2(9), 89 (2015)

19. N. Bulusu, J. Heidemann, D. Estrin, IEEE Personal. Commun., 7(5), 28 (2000)

20. E. Cagno, G. J. L. Micheli, C. Jacinto, D. Masi, Int. J. Ind. Ergon., 44(1), 60 (2014)

21. M. Carolan, Geoforum, 90, 142 (2018)

22. A. J. Chaghoshi, J. K. Jazani, S. Jafari, Glob. J. Manag. Stud. Res., 3(1), 13 (2016)

23. B. Chang, C.-W. Chang, C.-H. Wu, Expert Syst. Appl., 38(3), 1850 (2011)

24. A. Chauhan, A. Singh, S. Jharkharia, J. Air Waste Manag. Assoc., 68(2), 100 (2018)

25. J. K. Chen, I. S. Chen, Expert Syst. Appl., 37(3), 1981 (2010)

26. R. Chen, Food Control, 51, 70 (2015) 
27. S. L. Chen, Y. Y. Chen, C. Hsu, Sensors, 14(4), 6144 (2014)

28. L. Da Xu, W. He, S. Li, IEEE Trans. Ind.Inform., 10(4), 2233 (2014)

29. C. Decker, M. Berchtold, L. W. F. Chaves, M. Beigl, D. Roehr, T. Riedel, D. Herzig, The Internet of Things, 155 (Springer, Berlin, Heidelberg, 2008)

30. DHL, 2015. Internet of Things in logistics (2017) https://www.dpdhl.com

31. A. Diabat, K. Govindan, Resour. Conserv. Recycl., 55(6), 659 (2011)

32. A. L. Diedrichs, G. Tabacchi, G. Grünwaldt, M. Pecchia, G. Mercado, F. G. Antivilo, Biennial Congress of Argentina (ARGENCON). IEEE, 525 (2014)

33. N. Eddy, Gartner: 21 Billion IoT devices to invade by 2020. Information Week (2015) www.informationweek.com

34. Ericsson, 2016, "Consumer view on future wearables beyond healthand wellness", Ericsson Consumer lab Wearable technology and Internet of Things, https://www.ericsson.com

35. M. Ferretti, F. Schiavone, Bus. Process Manag. J., 22(2), 271 (2016)

36. M. Fritz, G. Schiefer, Int. J. Prod. Econ., 117(2), 317 (2009)

37. Gartner, Top 10 Internet of Things technologies for 2017 and 2018 (2016) www.gartner.com

38. Gartner, Drive your own disruption (2018) https://www.accenture.com

39. P. Ghashghaee, Smart manufacturing: role of Internet of Things in process optimization (2016) https://dspace.cc.tut.fi

40. S. K. Gupta, S. Kumar, Wesleyan Journal of Research, 51(13)-42, 45 (2020)

41. G. K. Haddud, Bus. Strateg. Environ., 18(3), 177e191 (2017)

42. Juels, Sustainability, 8(12), 1e12. (2006)

43. S. A. Kelly, J. Jabar, Int. J. Innov. Appl. Stud., 8(3), 1112 (2013)

44. S. Kumar, S. K. Gupta, M. Voda, Geographia Technica, 16(1), 87 (2021)

45. S. Kumar, Journal of Emerging technologies and Innovative research., 06(5), 194(2019)

46. K. J. Jia,Wu, C. H. Lee, M. K. Lim, T. D. Bui, C. C. Chen, J. Clean. Prod., 195, 406e417 (2012)

47. M. K. Gubbi Lim, W. P. Wong, Y. C. Chen, Y. Zhan, A framework for evaluating the performance of sustainable service (2013)

48. S. Lee, Y. Geum, H. Lee, Y. Park, J. Clean. Prod., 32, 173e182 (2015)

49. C. H. Li, G. H. Tzeng, M. H. Lee, P. Y. Lee, Tourism Manag Perspect., 6, 95e107 (2015)

50. L. Lim, S. A. Shamee, J. Jabar, Int. J. Innov. Appl. Stud., 8(3), 1112 (2013)

51. Mattern, Floerkemeier., Netw. Intell. Stud., 1(2), 127e135 (2010)

52. C. J. Navajo Liao, C. C. Chen, Y. Lin, C. F. Tsai, Int. J. Prod. Econ., 181, 419e440 (2010)

53. K. M. Ojha, W. P. Wong, Ind. Manag. Data Syst., 115(3), 436e461 (2015)

54. J. M. Willison, R. P. Cote, J. Clean. Prod., 17(3), 348e353 (2009)

55. Riggins, Wamba, J. Clean. Prod., 195, 908e918. (2015)

56. Reaidy et al., Sci. Total Environ., 610,391e401 (2015)

57. J. M. Wang, R. P. Cote, J. Clean. Prod., 17(3), 348e353 (2013)

58. Z. Xing, Waste Manag, 64, 358 (2013)

59. Zeng, Ecol. Indicat., 56, $218 \mathrm{e} 228$ (2015) 